\title{
Grampian migmatites in the Buchan Block, NE Scotland
}

\author{
T. E. JOHNSON ${ }^{1 *}$, C. L. KIRKLAND ${ }^{1}$, S. M. REDDY ${ }^{1} \&$ S. FISCHER ${ }^{2}$ \\ ${ }^{1}$ Department of Applied Geology, The Institute for Geoscience Research (TIGeR), Curtin \\ University, GPO Box U1987, PerthWA 6845, Australia (tim.johnson@curtin.edu.au) \\ ${ }^{2}$ Department of Earth \& Environmental Science, University of St Andrews, Irvine Building, \\ North Street, St Andrews, KY16 9SY, Scotland
}

Short title: Grampian migmatites in the Buchan Block

\begin{abstract}
Rocks exposed along the Scottish coast between Fraserburgh and Inzie Head contain information critical to understanding the evolution of the Buchan Block, the type locality for low-pressure, high-temperature regional metamorphism, and its relationship with the rest of the Grampian terrane, one of the major tectonostratigraphic components of the Scottish Caledonides. The $\sim 8 \mathrm{~km}$ long section traverses a regional network of shear zones and, at the highest grades around Inzie Head, passes into the core of the Buchan Anticline, a large-scale open fold that is commonly regarded as a late structure, post-dating metamorphism. The metasedimentary rocks increase in grade from upper amphibolite to granulite facies and preserve unequivocal evidence for partial melting. The diatexite migmatites around Inzie Head, along with other gneissose units within the Buchan Block, have been regarded as allochthonous Precambrian basement rocks that were thrust into their current position during Grampian orogenesis. However, field observations show that the onset of in situ partial melting in metapelitic rocks, which was associated with the formation of garnet-bearing aplites and associated pegmatites, occurred around Fraserburgh, where shear fabrics are absent. Thus, the rocks preserve a continuous metamorphic field gradient that straddles the shear zone network. This observation supports an alternative interpretation that anatexis was the result of the mid-Ordovician (Grampian) metamorphism, rather than an older tectonothermal event, and that the Inzie Head gneisses are autochthonous. Using an average mid-Dalradian pelite as a plausible representative protolith, phase equilibria modelling satisfactorily reproduces the observed appearance and disappearance of key minerals providing that peritectic garnet produced with the first formed melts (represented by the garnet-bearing aplites) depleted the source rocks in $\mathrm{Mn}$. The modelled metamorphic field gradient records a temperature increase of at least $150{ }^{\circ} \mathrm{C}$ (from around $650{ }^{\circ} \mathrm{C}$ near
\end{abstract}

This article has been accepted for publication and undergone full peer review but has not been through the copyediting, typesetting, pagination and proofreading process, which may lead to differences between this version and the Version of Record. Please cite this article as doi: $10.1111 /$ jmg. 12147

This article is protected by copyright. All rights reserved. 
Fraserburgh to in excess of $800{ }^{\circ} \mathrm{C}$ at Inzie Head) but is isobaric at pressures of 2.7-2.8 kbar, suggesting the Buchan Anticline developed synchronous with partial melting. The Buchan Anticline is likely an expression of crustal thinning and asthenospheric upwelling, which produced voluminous gabbroic intrusions that supplied the heat for Buchan metamorphism.

Key words: Phase equilibria modelling; Grampian metamorphism; Buchan Block; Dalradian metapelitic migmatite; manganese.

\section{INTRODUCTION}

The Grampian Highlands, bound to the north by the Great Glen Fault and to the south by the Highland Boundary Fault, are dominated by metasedimentary rocks of the Neoproterozoic Dalradian Supergroup that have been fundamental to our understanding of metamorphism (Barrow, 1893, 1912; Read, 1923; Tilley, 1925). The Buchan Block is a discrete structurallybound crustal package in the north-east Grampian Highlands that exhibits differences in its sedimentological, structural and metamorphic history compared to the rest of the Grampian terrane. The Buchan Block contains the type locality for high-temperature $(T)$, low-pressure $(P)$ regional metamorphism (Read, 1923, 1952) that is associated with a warmer geotherm than that required for Barrovian metamorphism (Harte \& Hudson, 1979), which characterises rocks elsewhere in the Grampian Highlands.

The rocks of the Buchan Block define a broad horseshoe-shaped outcrop, which hosts a regional system of shear zones (Ashcroft et al., 1984; Kneller \& Leslie, 1984; Fettes et al., 1986; Goodman, 1994) that are spatially and temporally associated with the intrusion of mafic and ultramafic rocks at around $471 \mathrm{Ma}$ (Dempster et al., 2002; Oliver et al., 2002; Carty et al., 2012) (Fig. 1a). Within the Buchan Block, migmatitic gneisses crop out at a number of localities that are broadly coincident with the shear zone network (Fig. 1a). On the basis of structural and geochronological evidence, the gneisses have been interpreted to be of Precambrian age and, with the overlying rocks of the Buchan Block, to represent an allochthonous terrane (Sturt et al., 1977; Ramsay \& Sturt, 1979). Although the region is now commonly regarded as autochthonous (Stephenson et al., 2013b), the status of the gneissic rocks is still debated (Viete et al., 2014). While some propose that some or all are products of metamorphism in the Neoproterozic (c. 1000-700 Ma) (Sturt et al., 1977; Ramsay \& Sturt, 1979; Viete et al., 2010; Viete et al., 2014), others suggest partial melting occurred due to metamorphism in the mid-Ordovician (c. $470 \mathrm{Ma}$ ) as part of the Grampian Orogeny (Ashworth, 1975; Baker \& Droop, 1983; Johnson et al., 2001b; Johnson et al., 2003).

The $\sim 8 \mathrm{~km}$ long coastal section between Fraserburgh and Inzie Head exposes high grade metasedimentary rocks that straddle the regional shear zone network. The rocks increase in metamorphic grade towards the east, where granulite facies migmatitic gneisses in the core of the Buchan Anticline, a large-scale open fold considered to be a late (postmetamorphic) structure (Stephenson et al., 2013b), are intermingled with sheets of diorite. Based on a Rb-Sr whole rock age of $691 \pm 39 \mathrm{Ma}$ (Sturt et al., 1977) and a single grain SIMS ${ }^{206} \mathrm{~Pb} /{ }^{238} \mathrm{U}$ zircon age of $988 \pm 23 \mathrm{Ma}$, the Inzie Head gneisses have been interpreted as a sliver of Precambrian basement rocks thrust into their current position during Grampian orogenesis (Ramsay \& Sturt, 1979; Viete et al., 2014). We re-examine the rocks between Fraserburgh and Inzie Head using field observations combined with phase equilibria modelling with the aim of better understanding the metamorphic history of the migmatitic gneisses and the age of the Buchan Anticline.

This article is protected by copyright. All rights reserved. 


\section{REGIONAL GEOLOGY}

The Grampian terrane, comprising the Dalradian Supergroup, its basement and intrusive rocks, is one of several major crustal blocks that amalgamated during the Caledonian Orogeny to form the northern part of the British Isles. The major component of this terrane, the Dalradian Supergroup, is a sequence of deformed and metamorphosed midNeoproterozoic to early Palaeozoic rocks dominated by clastic sedimentary rocks, with some carbonate and volcanic units, which are intruded by igneous rocks ranging in composition from ultramafic to granitic. Most rocks were affected by the mid-Ordovician Grampian Orogeny (Lambert \& McKerrow, 1976), which caused polyphase deformation and regional metamorphism related to accretion of oceanic arcs to the Laurentian margin (Dewey \& Shackleton, 1984). The Grampian Orogeny lasted some 30 million years, as constrained by the latest age of arc magmatism in the Midland Valley Terrane (c. 490-489 Ma; Chew et al., 2007) and the youngest regional Ar/Ar cooling ages for the Dalradian (c. $461 \mathrm{Ma}$; Dempster et al., 1985; Viete et al., 2013). Barrovian metamorphism occurred during a short-lived tectonothermal event between c. 473 and $465 \mathrm{Ma}$ (Oliver et al., 2000; Baxter et al., 2002; Dewey, 2005; Viete et al., 2013), which is interpreted to have been driven largely by advection of heat from the lower crust rather than by thermal relaxation of significantly thickened crust (Ague \& Baxter, 2007; Viete et al., 2013).

Recent reviews on the origin and evolution of rocks within the wider Grampian terrane are provided by Stephenson et al. (2013a), Tanner (2014) and Dewey et al. (2015), and of the geology of the north-east Grampian Highlands, including the Buchan Block, by Stephenson et al. (2013b). Although a more complex scheme for classifying sequences of Grampian deformation has been advanced (Viete et al., 2010), here we follow the traditional $\mathrm{D}_{1}-\mathrm{D}_{4}$ regional nomenclature (e.g. Stephenson et al., 2013a).

\section{Geology of the Buchan Block}

The rocks of the Buchan Block in the north-east Grampian Highlands define a broad horseshoe-shaped outcrop pattern of Dalradian rocks whose distribution is controlled by two open, broad, upright folds, the Turriff Syncline and the Buchan Anticline (Fig. 1a). Although precise correlation with Dalradian strata elsewhere in the Grampian terrane is commonly problematic, rocks at lower stratigraphic levels within the Buchan Block, which largely comprise semipelites, graphitic metapelites and psammites with minor metalimestones and metavolcanic rocks, are generally ascribed to the Argyll Group (Fettes et al., 1991). Rocks at higher stratigraphic levels in the core of the Buchan Block consist of a thick sequence of metaturbidites belonging to the Southern Highland Group.

The Buchan Block is bounded to the south and west by major crustal structures ('lineaments') that separate it from the rest of the Grampian terrane (Fig. 1a). To the south, the east-west Deeside Lineament is associated with voluminous granite plutons, either side of which the Dalradian statigraphy is generally coherent. To the west, the NNE-SSW PortsoyDuchray Hill Lineament was active during deposition of the Dalradian sediments and was a locus for subsequent deformation and intrusion of ultramafic and mafic magmas, across which the stratigraphy is highly disrupted (Fettes et al., 1986; Fettes et al., 1991; Goodman, 1994; Stephenson et al., 2013b).

There has been much debate regarding the timing of large-scale folds within the Buchan Block (Sutton \& Watson, 1956; Johnson, 1962; Treagus \& Roberts, 1981; Stephenson \& Gould, 1995; Viete et al., 2010). Rocks of the Southern Highland Group exhibit locally complex open to tight upright folds in which a spaced pressure solution cleavage is particularly well developed in metapsammite horizons. Read (1955) considered

This article is protected by copyright. All rights reserved. 
these rocks to sit on the upper limb of a major SE-verging recumbent (regional $\mathrm{F}_{1}$ ) fold, called the Banff Nappe, although the small-scale vergence of $F_{1}$ folds is generally towards the NW. On the east coast around Collieston (Fig. 1a), recumbent, tight to isoclinal, east-verging $F_{1}$ folds occur in rocks that are regionally inverted, and a major early fold closure must occur between here and Fraserburgh, where the succession is right way up (Stephenson et al., $2013 \mathrm{~b}$ ). The axial surface of this fold, which sits within poorly exposed gneisses, was regarded as the hinge-zone of the Banff Nappe by Read (1955) and Read \& Farquhar (1956), which subsequent workers tentatively considered to be a northern continuation of the $\left(\mathrm{F}_{1}\right)$ Tay Nappe (Stephenson et al., 2013a). On the western limb of the Turriff Syncline, west of Banff, the general shallow regional dip becomes subvertical and the rocks lie on the steep limb of the Boyndie Syncline, regarded by some as a major early (regional $F_{1}$ ) fold (Sutton \& Watson, 1956; Treagus \& Roberts, 1981) and by others as a later $\left(\mathrm{F}_{3}\right)$ structure (Johnson \& Stewart, 1960; Johnson, 1962; Fettes, 1970).

$\mathrm{D}_{2}$ structures within the Grampian terrane are generally associated with a strong component of simple shear (e.g. Stephenson et al., 2013a), and a number of major shear zones occur within the Buchan Block. On the eastern edge of the Cowhythe Psammite Formation, east of Portsoy (Fig. 1), highly deformed rocks mark the position of the Boyne Line of Read (1955), which he interpreted as a major 'slide' (low-angle fault) underlying the Banff Nappe. Thrust-related fabrics at the western margin of the Cowhythe Psammite Formation, termed the Portsoy Thrust by Elles (1931), are now regarded as the eastern limit of the $\sim 1 \mathrm{~km}$-wide Portsoy Shear Zone, which forms the northernmost section of the PortsoyDuchray Hill Lineament (Fettes et al., 1986; Goodman, 1994), part of the regional set of shear zones that bound much of the Buchan Block (Ashcroft et al., 1984) (Fig. 1a). Major stratigraphical, structural and metamorphic discontinuities across the Portsoy-Duchray Hill Lineament indicate early west-directed thrusting (Baker, 1987; Beddoe-Stephens, 1990), although in detail the shear zones record a complex history involving both shortening and extension with a significant component of pure shear flattening (Ashcroft et al., 1984; Dempster et al., 1995; Carty, 2001; Viete et al., 2010).

Syntectonic mafic and ultramafic igneous rocks of the north-east Grampian Basic Suite are spatially and temporally associated with the shear zones. Upper amphibolite facies metagabbros at Portsoy dated at $471.3 \pm 0.6 \mathrm{Ma}$ were emplaced synchronous with $\mathrm{D}_{2}$ shearing that had ceased by c. $471 \mathrm{Ma}$ (Carty et al., 2012). This age for the Portsoy Gabbro falls within the range of less precise ages determined for metagabbroic rocks elsewhere in the Buchan Block (Carty, 2001; Dempster et al., 2002; Oliver et al., 2008).

The large wavelength Turriff Syncline and Buchan Anticline (Fig. 1a) have axes that plunge gently to the NNE. Both folds are generally interpreted as relatively late (probably regional $\mathrm{D}_{4}$ ) structures that post-date metamorphism (Stephenson \& Gould, 1995; Stephenson et al., 2013b). However, Read \& Farquhar (1956, p131) considered the Buchan Anticline as early, some form of syn-metamorphic gneiss dome that rose into the lower limb of Read's Banff Nappe, which resulted from "the eastward and upward movement of the migmatized core of the great fold".

Porphyroblast growth and the peak of Buchan metamorphism occurred post- $\mathrm{D}_{1}$ and pre- $\mathrm{D}_{3}$, synchronous with regional $\mathrm{D}_{2}$ deformation (Johnson, 1962; Treagus \& Roberts, 1981; Kneller \& Leslie, 1984). Thus, magmatism, $\mathrm{D}_{2}$ deformation and the climax of Buchan metamorphism were approximately coeval at around $471 \mathrm{Ma}$ (Kneller \& Leslie, 1984; Dempster et al., 1995; Carty et al., 2012). The lowest grade regional metamorphism in the Buchan Block occurs in the core of the Turriff Syncline, where rocks of the Southern Highland Group record greenschist facies (biotite-zone) conditions. Metamorphic grade increases to the west, south and east, with the prograde appearance of cordierite then andalusite indicating relatively low $\mathrm{d} P / \mathrm{d} T$ conditions that characterise Buchan-type

This article is protected by copyright. All rights reserved. 
metamorphism (Chinner, 1966; Harte \& Hudson, 1979). Staurolite, which occurs in metapelitic rocks on the western limb of the Turriff Syncline, may indicate higher pressures (Harte \& Hudson, 1979; Pattison \& Tracy, 1991) or, alternatively, that the rocks record a polymetamorphic evolution (D. Pattison, Pers. Comm.). The highest-grade regional metamorphic rocks occur as migmatitic gneisses that are spatially associated with the regional shear zones and intrusive rocks of the North-east Grampians Basic Suite. Many contain granulite facies assemblages consistent with temperatures in excess of $800{ }^{\circ} \mathrm{C}$ (Baker \& Droop, 1983; Johnson et al., 2001a). Hornfels occurring in the roof-zones, inner aureoles and as xenoliths within the mafic and ultramafic intrusions record pressures of 4.5-5.0 kbar, implying that the mafic-ultramafic rocks were intruded as a more or less continuous subhorizontal sheet (Droop \& Charnley, 1985). West of the Portsoy-Duchray Hill Lineament metapelitic rocks preserve evidence for replacement of andalusite by kyanite and the transition to higher $\mathrm{d} P / \mathrm{d} T$ conditions associated with Barrovian metamorphism, which characterizes Dalradian rocks outside of the Buchan Block (Chinner, 1966).

A number of granite intrusions within the Grampian terrane pre-date Grampian deformation (Tanner, 1996; Tanner et al., 2006). In the Buchan Block, U-Pb dating of zircon has yielded emplacement ages of around 600 Ma for the Portsoy and Keith Granites (Barreiro, 1998), synchronous with basaltic volcanism and the deposition of uppermost Argyll Group (Tayvallich Subgroup) sediments (Halliday et al., 1989; Dempster et al., 2002). Geochemical and isotopic data led Tanner et al. (2006) to interpret these intrusions as 'Atype' granites emplaced during crustal rifting and continental breakup.

Most intrusive rocks within the Buchan Block are synchronous with, or post-date Grampian orogenesis and are confined to the north-east Grampian Highlands. Although mafic and ultramafic intrusive rocks were subdivided by Read (1919) into an older and younger series based largely on the intensity of deformation and alteration, this subdivision is probably unwarranted (Munro \& Gallagher, 1984), with most recording ages of c. $470 \mathrm{Ma}$ (see above). Based on geochemical data, rocks of the north-east Grampian Basic Suite are interpreted as mantle melts derived by lithospheric extension and decompression melting of the asthenosphere (Viete et al., 2010).

Grampian-age granites are peraluminous and have initial ${ }^{87} \mathrm{Sr} /{ }^{86} \mathrm{Sr}$ values of $0.71-0.72$ consistent with a substantial crustal component within the magmas (Pidgeon \& Aftalion, 1978; Harmon, 1984). Age data give crystallization ages of c. 470 Ma (Pidgeon \& Aftalion, 1978; Kneller \& Aftalion, 1987; Oliver et al., 2000), synchronous with intrusion of the metagabbros and regional metamorphism (Carty et al., 2012). Geochemical evidence is consistent with the Grampian granites having formed via partial melting of Dalradian metasedimentary rocks (Johnson et al., 2003). Undeformed (Late Caledonian) granites emplaced after c. $460 \mathrm{Ma}$ show no association with mafic magmatism (Oliver, 2001). Of these, relatively early (c. 460-435 Ma) intrusions are strongly peraluminous ('S-type') and have initial ${ }^{87} \mathrm{Sr} /{ }^{86} \mathrm{Sr}$ ratios identical to Grampian granites, whereas later (c. 435-400 Ma) bodies are metaluminous to weakly peraluminous ('I-type') and have lower initial ${ }^{87} \mathrm{Sr} /{ }^{86} \mathrm{Sr}$ ratios reflecting more juvenile input (Oliver, 2001).

\section{FIELD RELATIONS}

\section{Fraserburgh}

On Kinnaird Head, Fraserburgh (Fig. 1), Tayvallich Subgroup (locally the Strichen Formation; uppermost Argyll Group) rocks are dominated by thinly interbedded metapelite and calcsilicate (Johnson et al., 2000). Metapelite layers (Fig. 2a,b) contain porphyroblasts of cordierite, andalusite and prismatic sillimanite in a matrix rich in biotite, quartz, feldspar and

This article is protected by copyright. All rights reserved. 
fibrolite. Prismatic sillimanite, which is partially to completely replaced by retrograde muscovite, first appears on the west side of Broadsea Shore (Fig. 1c). Silica-undersaturated (quartz-absent) horizons contain stubby porphyroblasts of corundum, confirming that the rocks are at temperatures above the terminal breakdown of muscovite. Most calc-silicate rocks are green in colour reflecting a high modal abundance of diopside with clinozoisite and/or calcic amphibole. Pale marble bands mostly contain abundant calcite with scapolite, diopside, quartz and plagioclase (Johnson et al., 2000).

The rocks at Fraserburgh are affected by three regional deformation 'events'. $F_{1}$ forms tight to isoclinal recumbent folds that verge towards the NW; $\mathrm{S}_{1}$ is recrystallized by subsequent metamorphism. The second generation of folds (regional $\mathrm{F}_{3}$ ) are more locally developed, forming smaller-scale, more upright folds that are broadly coaxial with the earlier structures. Minerals that grew during peak metamorphism define a weak $\mathrm{S}_{3}$ fabric, the peak of metamorphism having been attained pre- to syn- $\mathrm{D}_{3}$ (Treagus \& Roberts, 1981). All earlier structures are re-oriented by gentle open folds, probably $\mathrm{F}_{4}$, ascribed to differential uplift of the Buchan Block (Dempster, 1985). The intense regional $\mathrm{D}_{2}$ shearing that is particularly strongly developed around Portsoy is not present at Fraserburgh, being restricted to levels stratigraphically beneath the Tayvallich Subgroup (Kneller, 1987a). However, the regional network of shear zones is mapped crossing the coast at Fraserburgh Bay, a short distance to the east (Ashcroft et al., 1984; Fig. 1).

Irregular sheet-like bodies of aplite and pegmatite, up to $1 \mathrm{~m}$ thick, occur on Kinnaird Head and further to the east. The aplites contain small $(0.2-0.5 \mathrm{~mm}$ diameter) euhedral grains of spessartine-rich garnet, rare biotite and tourmaline, and are in petrographic (i.e. mineralogical and microstructural) continuity (Marchildon \& Brown, 2003) with irregular sheets of pegmatite, suggesting a genetic relationship (Johnson et al., 2000; Fig. 2a). Marble bands adjacent to the pegmatites contain wollastonite, grossular garnet and vesuvianite that developed via reaction with $\mathrm{H}_{2} \mathrm{O}$-rich fluids derived from the pegmatites (Johnson et al., 2000). The metapelitic rocks adjacent to the aplites contain a network of small veinlets that interconnect with successively larger veins and, ultimately, the aplites (Fig. 2a,b). These features are interpreted to record in situ partial melting of the metapelitic rocks, with melt segregation and migration forming successively larger sheet-like bodies. The inferred low degree of partial melting, peraluminous (garnet-bearing) composition of the aplites and their close association with pegmatite suggests high $a\left(\mathrm{H}_{2} \mathrm{O}\right)$ near-solidus anatexis of the metapelitic rocks. The first convincing evidence for in situ partial melting (i.e. the 'melt' in isograd) of metapelite, in the form of small veinlets of granitic leucosome, appears between Broadsea Shore and Kinnaird Head (Fig. 1c). The earlier interpretation of Johnson et al. (2001b), who suggested this isograd lay somewhere unexposed within Fraserburgh Bay to the east, is incorrect.

\section{Cairnbulg to Inzie Head}

Metasedimentary migmatites of the Inzie Head Formation dominate rocks from West Haven on the east side of Fraserburgh Bay to Inzie Head (Fig. 1d). The migmatites, described in detail by Kneller (1987b) and Johnson et al. (2001a,b, 2003), are mostly strongly retrogressed diatexites containing abundant biotite-rich schlieren and schollen of cordierite-spotted metapelite, semi-pelite, psammite and diopside-rich calc-silicate that commonly occur in disaggregated trains that define a crude 'ghost' stratigraphy. A variably weak to intense fabric, probably regional $\mathrm{D}_{2}$, is developed within the migmatites that dips at moderate to steep angles towards the north-west and is defined by the alignment of biotite-rich schlieren and flattened schollen.

This article is protected by copyright. All rights reserved. 
All migmatised pelitic and semi-pelitic rocks contain grey-coloured leucosome containing small (up to $2 \mathrm{~mm}$ across) euhedral grains of cordierite, most of which are pseudomorphed by fine-grained aggregates of white mica and chlorite (Fig 2c,d). Schollen of biotite-rich metapelite contain abundant ovoid pophyroblasts of cordierite, but most lack sillimanite. Further upgrade, around Point of Whitelinks, a second leucosome type containing conspicuous porphyroblasts of garnet (up to $20 \mathrm{~mm}$ in diameter) mingles with the grey cordierite-bearing leucosome (Fig. 2d). Leucosome garnet is partially to completely replaced by biotite and dark green aggregates rich in chlorite, and the rocks contain abundant rounded schollen of cordierite-spotted metapelite and larger blocks of calcareous psammite (Fig. 2d). The first appearance of garnet in the section between Cairnbulg and Inzie Head occurs close to the south-eastern extent of Inverallochy village, shown by the garnet in isograd on Fig. 1d (Johnson et al., 2001b). At the highest grades, garnet is absent and leucosomes contain large (up to $30 \mathrm{~mm}$ long) stubby prismatic aggregates rich in chlorite interpreted as pseudomorphs after orthopyroxene (Johnson et al., 2001 ab) (Fig. 2e). The last occurrence of garnet occurs in rocks 50-100 m southeast (up grade) of the first appearance of the orthopyroxene pseudomorphs. The rocks here, as elsewhere in the migmatised section, are strongly retrogressed (Fig. 2e), and at the highest grades it is unclear if biotite is a peak or retrograde mineral (or both).

Irregular patches and sheets of granite containing diffuse, semi-digested schollen occur throughout the section. The granite sheets are interconnected to, and in petrographic continuity with, the host migmatites suggesting they represent in source leucosome that segregated from the residual source rocks (Fig. 2c). Sheets of diorite ranging in size from a few tens of centimetres to several hundred metres across and oriented sub-parallel to the foliation are also abundant (Fig. 1d). In all cases the diorites are intimately mingled and/or hybridised with granitic leucosome (Fig. 2f), indicating that intrusion of the diorite was synchronous with partial melting in the migmatites (Johnson et al., 2000).

\section{Summary}

Based on field relations, the inferred prograde sequence of changes in the main silicate peak metamorphic assemblage within 'normal' (i.e. silica-saturated subaluminous) metapelitic rocks from Fraserburgh to Inzie Head is given below (for localities see Fig. 1c,d):

- $\quad c d+b i+$ and $+\mathrm{ksp}+\mathrm{pl}+\mathrm{q}$ (e.g. west of Broadsea Shore)

- $\quad \mathrm{cd}+\mathrm{bi}+\mathrm{sill}+\mathrm{ksp}+\mathrm{pl}+\mathrm{q} \quad$ (e.g. Broadsea Shore)

- $\quad c d+b i+$ sill $+\mathrm{ksp}+\mathrm{pl}+\mathrm{q}+$ melt (e.g. Kinnaird Head)

- $c d+b i+k s p+p l+q+$ melt (e.g. West Haven)

- $\mathrm{g}+\mathrm{cd}+\mathrm{bi}+\mathrm{ksp}+\mathrm{pl}+\mathrm{q}+$ melt (e.g. Point of Whitelinks)

- $\mathrm{g}+\mathrm{opx}+\mathrm{cd}+\mathrm{bi}+\mathrm{ksp}+\mathrm{pl}+\mathrm{q}+$ melt (up to 50-100 m SE of the opx-in isograd near St Combs)

- $\quad$ opx $+\mathrm{cd}+\mathrm{ksp}+\mathrm{pl}+\mathrm{q}+$ melt \pm bi (e.g. Inzie Head)

Sillimanite first appears on the western edge of Broadsea Shore (Fig. 1c). Isograds recording the first evidence for situ partial melting ('melt' in) and the first appearance of garnet and orthopyroxene in metapelitic rocks are shown in Fig. 2c,d.

This article is protected by copyright. All rights reserved. 


\section{PHASE EQUILIBRIA MODELLING}

Phase equilibria modelling was undertaken to examine whether the overall sequence of mineralogical changes observed in the field and summarised above can be satisfactorily reproduced using a representative average bulk rock composition. Phase equilibria calculations are based on the average major element oxide bulk composition of Argyll Group (middle Dalradian) metapelitic rocks $(n=38)$ of Atherton \& Brotherton (1982), for which the amount of iron that is $\mathrm{Fe}_{2} \mathrm{O}_{3}$ is based on wet chemical analyses of 34 of the samples. Calculations using THERMOCALC (Powell \& Holland, 1988) are in the $\mathrm{MnO}-\mathrm{Na}_{2} \mathrm{O}-\mathrm{CaO}-$ $\mathrm{K}_{2} \mathrm{O}-\mathrm{FeO}-\mathrm{MgO}-\mathrm{Al}_{2} \mathrm{O}_{3}-\mathrm{SiO}_{2}-\mathrm{H}_{2} \mathrm{O}-\mathrm{TiO}_{2}-\mathrm{O}$ (MnNCKFMASHTO) model pelite system and use the end-member thermodynamic data of Holland \& Powell (2011) (ds62 dataset as generated on 06/02/14) and recently calibrated $a-X$ models (White et al., 2014a,b). Phase diagrams were contoured for the abundance ('mode') and composition of phases using TC Investigator (Pearce et al., 2015). Bulk compositions used in the phase equilibria calculations (in mol.\%) are shown in Table 1.

\section{Average Argyll Group metapelite}

A $P-T$ pseudosection for the average Argyll Group metapelite composition with 3 mol.\% $\mathrm{H}_{2} \mathrm{O}$, in which all fields contain plagioclase, quartz, ilmenite and magnetite, is shown in Fig. 3a. For this $\mathrm{H}_{2} \mathrm{O}$ content, which was chosen to be sufficient to just saturate the solidus at 2.7$2.8 \mathrm{kbar}$, the solidus becomes fluid absent above 2.8-2.9 kbar. At low temperatures the $\mathrm{H}_{2} \mathrm{O}$ content is artificially low, leading to some $\mathrm{H}_{2} \mathrm{O}$-absent subsolidus assemblages. For the $P-T$ range considered, garnet is stable at all but the lowest $P-T$ conditions and at very low- $P$ and high- $T$, cordierite is stable in all fields except at high- $P$ and low- $T$ and orthopyroxene occurs only at high temperature $\left(>750{ }^{\circ} \mathrm{C}\right)$ and low pressure $(\sim 3 \mathrm{kbar}$ or less $)$. The calculated abundance (as mol.\%) of melt and garnet for the same $P-T$ range shown in Fig. 3a, as well as the composition of garnet in terms of the mole fraction of the spessartine component, $X(\mathrm{spss})$, are shown in Fig. 4. Phase diagrams contoured for other variables are in Fig. S1.

The phase diagram for the average Argyll Group metapelite (Fig. 3a) can satisfactorily reproduce near-solidus phase relations, as shown in an expanded area from 2.5$3.0 \mathrm{kbar}$ and $670-690{ }^{\circ} \mathrm{C}$ (Fig. 3b). Within this region, the stability fields recording the prograde appearance of garnet intersect the $\mathrm{H}_{2} \mathrm{O}$-saturated (wet) solidus, consistent with the onset of partial melting and formation of the garnet-bearing aplite sheets, both of which occur on or close to Kinnaird Head. This is consistent with a metamorphic field gradient that crosses the $\mathrm{H}_{2} \mathrm{O}$-saturated solidus at pressures of 2.7-2.8 kbar. Along a prograde path at this pressure (grey arrow in Fig. 3b), the subsolidus evolution predicts that rocks rich in cordierite, biotite and andalusite will cross the andalusite to sillimanite transition at 670-675 ${ }^{\circ} \mathrm{C}$ before the onset of partial melting and formation of small quantities of spessartine-rich garnet at $680-685^{\circ} \mathrm{C}$, all of which are consistent with observation.

By contrast, the phase diagram for the average Argyll Group metapelite (Fig. 3a) cannot explain observations within the higher-grade section between Cairnbulg and Inzie Head (Fig. 1d). Cordierite-rich metapelitic rocks within the lower-grade migmatites between Cairnbulg and Inverallochy generally lack sillimanite, consistent with the model predictions. However, these rocks do not contain any garnet, which is predicted at all suprasolidus conditions except at very low pressure $(<1.5 \mathrm{kbar})$ and high temperature $\left(>750{ }^{\circ} \mathrm{C}\right)$ (Figs $3 \mathrm{a}$ $\& 4 b)$. At higher temperatures the modelling predicts the appearance of orthopyroxene, but only at pressures at or below $3 \mathrm{kbar}$ (Fig. 3a). This maximum pressure constraint is similar to pressures inferred for near-solidus assemblages around Kinnaird Head (Fig. 3).

This article is protected by copyright. All rights reserved. 


\section{DISCUSSION}

\section{Modelling the $\boldsymbol{P}-\boldsymbol{T}-\boldsymbol{X}$ evolution}

Near-solidus phase relations based on the average Argyll Group metapelite

Phase equilibria modelling based on an average Argyll Group metapelite composition reproduces near-solidus phase relations around Fraserburgh at 2.7-2.8 kbar (Fig. 3a,b). A prograde evolution at these pressures predicts high-temperature subsolidus rocks rich in cordierite, biotite and andalusite that cross the andalusite to sillimanite transition before the onset of partial melting at the $\mathrm{H}_{2} \mathrm{O}$-saturated solidus at $680-685^{\circ} \mathrm{C}$. Crossing of the solidus coincides with the first appearance of garnet, consistent with the formation of small quantities $(<1 \mathrm{~mol} . \%)$ of peritectic garnet within the aplites (Fig. 4b,c). Garnet within the aplite sheets at Fraserburgh is rich in spessartine, the measured composition of which $[X(\mathrm{spss})=0.30$ 0.32 ; Johnson et al., 2000] matches well those calculated for the first formed garnet $[X(\mathrm{spss})$ $=0.28$ ] (Fig. 4c).

At higher temperatures, phase relations for the average composition do not match observation. Although the appearance of orthopyroxene is predicted at high- $T$ at a pressure of $3 \mathrm{kbar}$ or less, the $P-T$ stability field for garnet is much larger than field observations allow. The lack of correspondence between calculated and observed phase relations indicates that the average Argyll Group metapelite may not be an appropriate composition for the bulk of the migmatites with the Inzie Head Gneiss Formation. This might be used in support of the interpretation that the gneisses are allochthonous and were tectonically emplaced into the Dalradian sequence along and within the regional set of shear zones (e.g. Viete et al., 2014). However, of critical import is the field evidence for the onset of partial melting, which occurs to the west of the shear zone network within rocks that lack fabrics related to regional $\mathrm{D}_{2}$ deformation, consistent with the Inzie Head section representing a higher-grade extension to the low $-P$ metamorphic field gradient developed throughout the Buchan Block (Harte \& Hudson, 1979).

\section{Fractionation of $\mathrm{MnO}$ in peritectic garnet}

Manganese, which is present as a minor component (0.1-0.3 wt\%; Ague, 1991) in metapelitic rocks, has a critical effect on the stability of garnet (Symmes \& Ferry, 1992; Droop \& Harte, 1995; Mahar et al., 1997; White et al., 2014b). Although garnet is stable in subsolidus (greenschist and amphibolite facies) Barrovian rocks metamorphosed at significantly higher pressures, small quantities of $\mathrm{MnO}$ are also known to stabilize garnet in similarly low-grade rocks metamorphosed at low pressure, including in the Buchan Block (Harte \& Hudson, 1979; Hudson, 1980). Fractionation of Mn into early formed (cores) of garnet in subsolidus rocks may lead to changes in the effective bulk composition that affect their subsequent prograde evolution until temperatures are high enough to allow diffusional equilibration on length scales exceeding the size of porphyroblasts (Spear, 1988; Evans, 2004; KonradSchmolke et al., 2005). However, metamorphic fractionation may also occur in suprasolidus rocks by removal of peritectic phases that are produced with melt by incongruent breakdown of hydrate phases. Although entrainment of peritectic phases is known to have a significant effect on the composition of peraluminous granites (e.g. Stevens et al., 2007; Dorais \& Spencer, 2014), the potential effect on the residue is less well documented. We suggest that physical removal, or isolation, of spessartine-rich garnet that formed with the first formed melts (now represented by the garnet-bearing aplites) can explain the mineralogical evolution of the higher grade migmatites.

This article is protected by copyright. All rights reserved. 
To test this hypothesis, an isobaric (2.75 kbar) $T$-X(-garnet) pseudosection was calculated (Fig. 5) that varies from the composition of the average Argyll Group metapelite used in Fig. 3 (at $X=0$ with $0.09 \mathrm{~mol} . \% \mathrm{MnO}$ ) to a composition with a small quantity (0.6 mol.\%) of spessartine-rich garnet removed (for simplicity no melt was removed from the bulk composition, as this has no significant effect on the stability of the solid phases, as shown later; Fig. S3) such that only 0.005 mol.\% MnO remains $(X=1)$. The composition of the removed garnet is that measured (by electron probe microanalysis; EPMA) from a grain within an aplite sheet on Kinnaird Head (Johnson et al., 2000). The removal of this small amount of garnet has a trivial effect on the concentrations of other components within the bulk composition (the largest effect is on $\mathrm{FeO}$ contents that are reduced by just $2 \%$ relative to the original composition), but has a significant effect on $\mathrm{MnO}$ contents, which are reduced by around $95 \%$ (Table 1).

Although the stability of all other phases is practically unchanged, the stability of garnet at higher temperatures is greatly reduced by removal of the spessartine-rich garnet on crossing the solidus (Fig. 5). An isobaric prograde path (grey arrow on Fig. 5) that satisfies field observations occurs at around $X=0.8$, which equates to the effective removal of around $0.5 \mathrm{~mol} . \%$ early formed peritectic garnet. Along this path, new garnet growth (the garnet-in isograd at around $760{ }^{\circ} \mathrm{C}$ ) is predicted prior to the formation of orthopyroxene (orthopyroxene-in isograd at a little above $780^{\circ} \mathrm{C}$ ), which is followed by the disappearance of garnet (at $790-800{ }^{\circ} \mathrm{C}$ ).

Importantly, removal of peritectic garnet requires effective segregation and migration of the melt in which it formed. In deforming rocks, melt connectivity is predicted at melt fractions beyond around 7\% (Rosenberg \& Handy, 2005). For the minimal $\mathrm{H}_{2} \mathrm{O}$ content used in the modelling $\left(0.3 \mathrm{~mol} . \% \mathrm{H}_{2} \mathrm{O}\right.$ is predicted at the wet solidus $)$, melt fractions do not exceed this value until temperatures of around $750{ }^{\circ} \mathrm{C}$ (Figs $4 \mathrm{a} \& \mathrm{~S} 3 \mathrm{a}$ ). This suggests $\mathrm{H}_{2} \mathrm{O}$ contents were marginally higher than modelled (by around $1 \mathrm{~mol} . \%$ ). This small amount of additional $\mathrm{H}_{2} \mathrm{O}$ was probably supplied by nearby rocks with slightly higher temperature solidi that were still undergoing subsolidus dehydration.

\section{High-grade phase relations}

A $P-T$ pseudosection for the average Argyll Group metasedimentary rock with 0.5 mol.\% spessartine-rich garnet removed (i.e. the composition at $X=0.8$ on Fig. 5) appropriate for phase relations in the higher-grade migmatites between Cairnbulg and Inzie Head is shown in Fig. 6. The calculated abundance (in mol.\%) of melt and garnet and the $X$ (spss) of garnet are shown in Fig. 7 (see also Fig. S2). Calculated phase relations differ significantly from those for the average Argyll group composition (Fig. 3) only in the stability of garnet, which is stable at relatively high $P-T$; orthopyroxene stability is extended slightly to higher pressure, with this phase stable only below $3.5 \mathrm{kbar}$ and above $750{ }^{\circ} \mathrm{C}$.

Around Cairnbulg, most metapelitic migmatites are rich in cordierite and biotite but lack sillimanite. Thereafter the prograde metamorphic field gradient is constrained to cross the garnet in isograd followed by the orthopyroxene-in isograd. The high- $T$ end of the metamorphic field gradient, represented by rocks at Inzie Head, is constrained to fields containing orthopyroxene but lacking garnet. The observations are consistent with a nearisobaric metamorphic field gradient for the Inzie Head Gneiss Formation at 2.7-2.8 kbar (grey arrow in Fig. 6). At its high- $T$ end, orthopyroxene and cordierite-bearing assemblages are predicted to lack biotite as well as garnet. It is unclear whether biotite was exhausted at the metamorphic peak and grew later during retrogression, and/or whether some biotite was stable at the metamorphic peak due to small quantities of minor components (e.g. F, Cl) that cannot currently be modelled.

This article is protected by copyright. All rights reserved. 
Along this field gradient a maximum of around $1 \mathrm{~mol} . \%$ garnet is predicted, consistent with observation (Fig. 2d), whose composition matches well those grains analysed (by EPMA) from leucosome at Point of Whitelinks [ $X$ (spss) 0.03-0.11; Johnson, 1999] (Fig. $7 \mathrm{~b}, \mathrm{c})$. For the $\mathrm{H}_{2} \mathrm{O}$-content in the modelled bulk composition, which was chosen to be sufficient to just saturate the solidus at $2.7-2.8 \mathrm{kbar}$, a maximum of $15-20 \mathrm{~mol} . \%$ melt is predicted at the highest grades along the modelled field gradient (Fig. 7a). However, the rocks between Cainbulg and Inzie Head are diatexites rich in leucosome (broadly representing former melt) in which pre-anatectic sedimentary and structural features have generally been destroyed (Fig. 2c-e). Johnson et al. (2001b) suggested that the high inferred degrees of partial melting resulted from influx of an $\mathrm{H}_{2} \mathrm{O}$-rich fluid phase focussed along the shear zone network, an interpretation followed here. For example, calculations show that suprasolidus rocks at grades lower than the garnet in isograd produce $<10$ mol.\% melt for the chosen $\mathrm{H}_{2} \mathrm{O}$ content (Fig. 7a). Although constraining the precise degree of partial melting is difficult, melt fractions here are inferred to be significantly higher (see Fig. 2c). Importantly, neither $\mathrm{H}_{2} \mathrm{O}$ influx and the resulting increase in melt fraction nor loss of melt have any effect on the pressure or temperature stability of garnet or orthopyroxene, and consequently on the constraints imposed on the metamorphic field gradient (see Fig. S3).

\section{An isobaric metamorphic field gradient and regional implications}

The constraints imposed by phase equilibria modelling on near-solidus pressures at Fraserburgh using the average Argyll Group metapelite composition (Fig. 3), and those imposed by the appearance and disappearance of garnet and orthopyroxene at higher grades using a composition depleted in Mn (Fig. 6), are consistent with an isobaric metamorphic field gradient ranging from around $650{ }^{\circ} \mathrm{C}$ to in excess of $800{ }^{\circ} \mathrm{C}$ at pressures of $2.7-2.8 \mathrm{kbar}$. The metamorphic field gradient records the transition from subsolidus to suprasolidus conditions and from amphibolite to granulite facies conditions.

Assuming the calculated location of the andalusite-sillimanite reaction in the $P-T$ pseudosection is correct, pressures at the low-grade (high- $T$ subsolidus) end of the metamorphic field gradient cannot have been significantly lower than modelled, as they must lie above the intersection of this reaction and the $\mathrm{H}_{2} \mathrm{O}$-saturated solidus ( $\left.\sim 2.6 \mathrm{kbar}\right)$; however, pressures may have been somewhat higher, perhaps up to 3.5 bar (Fig. 6). The high-grade end of the metamorphic field gradient at Inzie Head is constrained by the prograde appearance of orthopyroxene and disappearance of garnet. The calculated uncertainties on the end member thermodynamic data associated with the orthopyroxene-in and garnet-out boundaries shown in Fig. 6 are 0.4 kbar ( 2 ). Consequently, if the metamorphic field gradient records any positive $\mathrm{d} P / \mathrm{d} T$ it is extremely small.

Importantly, the metamorphic field gradient straddles the regional shear zone network, passing into the core of the Buchan Anticline. This suggests that the migmatitic gneisses are not tectonically emplaced slivers of Precambrian basement, but represent rocks metamorphosed during the mid-Ordovician Grampian orogeny that form the high-grade end of the classic Buchan low-pressure regional metamorphic facies series (Harte \& Hudson, 1979).

The isobaric metamorphic field gradient indicates that the section between Fraserburgh and Inzie Head records metamorphism at a near-constant crustal depth of around $10 \mathrm{~km}$. Thus, the Buchan Anticline must be earlier than, or synchronous with, metamorphism and partial melting (i.e. syn- $\mathrm{D}_{2}$ ), as originally proposed by Read (1955) and Read \& Farquhar (1956). In this interpretation, the fold represents a regional scale thermal antiform most likely related to lithospheric extension and upwelling of the underlying asthenosphere that melted to produce the syn- $\mathrm{D}_{2}$ (meta)gabbros of the north-east Grampian Basic Suite that provided the

This article is protected by copyright. All rights reserved. 
heat for Buchan metamorphism (Viete et al., 2010). A large basic mass at shallow depths in consistent with a positive gravity anomaly $(+10-20 \mathrm{mGal})$ that characterises the Buchan Block but is particularly strong along its eastern margin, extending offshore to the northeast (Trewin \& Rollin, 2002, fig. 1.7). Metamorphic conditions reached granulite facies in the roof of the anticline resulting in extensive partial melting of fertile rocks. The Buchan Anticline is not the same generation as the Turriff Syncline, which folds lower-grade regional isograds (Fig. 1a), and is interpreted to be an earlier structure.

\section{CONCLUSIONS}

- Argyll Group metasedimentary rocks exposed along the coastal section between Fraserburgh and Inzie Head range in metamorphic grade from amphibolite to granulite facies and straddle the regional set of shear zones

- Near solidus metapelitic rocks can be modelled satisfactorily using an average Argyll Group metapelite composition, which predicts production of spessartine-rich peritectic garnet with the first formed $\left(\mathrm{H}_{2} \mathrm{O}\right.$-rich) melts

- Higher-grade rocks can be modelled using a composition relatively depleted in $\mathrm{Mn}$ due to physical removal of small quantities of pertitectic garnet produced with the first melts

- The rocks record an isobaric (2.7-2.8 kbar) metamorphic field gradient ranging from around $650{ }^{\circ} \mathrm{C}$ at Fraserburgh to in excess of $800{ }^{\circ} \mathrm{C}$ at Inzie Head

- The rocks partially melted as part of a brief and localised magmatically-driven mid Ordovician Grampian tectonothermal event (e.g. Oliver et al., 2000; Dewey, 2005; Viete et al., 2013) and are not allochthonous slivers of Precambrian gneiss tectonically emplaced into the Dalradian succession

- The Buchan Anticline is a pre- to syn-metamorphic structure and earlier than the Turriff Syncline. It represents a regional thermal high related to extension of the lithosphere and advective heating of the middle and upper crust following decompression melting of the asthenosphere.

\section{ACKNOWLEDGEMENTS}

TJ is indebted to R. White for funding fieldwork. J. Carty and C. Gärtner are thanked for fruitful discussions in the field. We are grateful to D. Viete for supplying an editable copy of the map that became Fig. 1a and for discussions about the origin of gneisses within the Buchan Block. We thank R. Palin, D. Pattison and D. Viete (again) for their constructive comments that led to a significant improvement in the final version, and to M. Brown for his ever-proficient editorial handling. For N.F.C. Hudson.

\section{REFERENCES}

Ague, J. J., 1991. Evidence for major mass transfer and volume strain during regional metamorphism of pelites. Geology, 19, 855-858.

Ague, J. J. \& Baxter, E. F., 2007. Brief thermal pulses during mountain building recorded by $\mathrm{Sr}$ diffusion in apatite and multicomponent diffusion in garnet. Earth and Planetary Science Letters, 261, 500-516.

Ashcroft, W. A., Kneller, B. C., Leslie, A. G. \& Munro, M., 1984. Major shear zones and autochthonous Dalradian in the north-east Scottish Caledonides. Nature, 310, 760-762.

This article is protected by copyright. All rights reserved. 
Ashworth, J. R., 1975. The sillimanite zones of the Huntly-Portsoy area in the north-east Dalradian, Scotland. Geological Magazine, 112, 113-136.

Atherton, M. P. \& Brotherton, M. S., 1982. Major element composition of the pelites of the Scottish Dalradian. Geological Journal, 17, 185-221.

Baker, A. J., 1987. Models for the tectonothermal evolution of the eastern Dalradian of Scotland. Journal of Metamorphic Geology, 5, 101-118.

Baker, A. J. \& Droop, G. T. R., 1983. Grampian metamorphic conditions deduced from mafic granulites and sillimanite-K-feldspar gneisses in the Dalradian of Glen Muick, Scotland. Journal of the Geological Society, 140, 489-497.

Barreiro, B., 1998. U-Pb systematics on zircon from the Keith and Portsoy granites, Grampian Highlands, Scotland. NERC Isotope Geosciences Laboratory Report Series 3.

Barrow, G., 1893. On an Intrusion of Muscovite-biotite Gneiss in the South-eastern Highlands of Scotland, and its accompanying Metamorphism. Quarterly Journal of the Geological Society of London, 49, 330-358.

Barrow, G., 1912. On the geology of Lower Dee-side and the southern Highland Border. Proceedings of the Geologists' Association, 23, 274-290.

Baxter, E. F., Ague, J. J. \& Depaolo, D. J., 2002. Prograde temperature-time evolution in the Barrovian type-locality constrained by $\mathrm{Sm} / \mathrm{Nd}$ garnet ages from Glen Clova, Scotland. Journal of the Geological Society, 159, 71-82.

Beddoe-Stephens, B., 1990. Pressures and temperatures of Dalradian metamorphism and the andalusite-kyanite transformation in the northeast Grampians. Scottish Journal of Geology, 26, 3-14.

Carty, J., 2001. Deformation, magmatism and metamorphism in the Portsoy shear zone, north-east Scotland, University of Derby.

Carty, J. P., Connelly, J. N., Hudson, N. F. C. \& Gale, J. F. W., 2012. Constraints on the timing of deformation, magmatism and metamorphism in the Dalradian of NE Scotland. Scottish Journal of Geology, 48, 103-117.

Chew, D. M., Graham, J. R. \& Whitehouse, M. J., 2007. U-Pb zircon geochronology of plagiogranites from the Lough Nafooey (= Midland Valley) arc in western Ireland: constraints on the onset of the Grampian orogeny. Journal of the Geological Society, 164, 747-750.

Chinner, G. A., 1966. The distribution of pressure and temperature during Dalradian metamorphism. Quarterly Journal of the Geological Society of London, 122, 159186.

Dempster, T. J., 1985. Uplift patterns and orogenic evolution in the Scottish Dalradian. Journal of the Geological Society, 142, 111-128.

Dempster, T. J., Hudson, N. F. C. \& Rogers, G., 1995. Metamorphism and cooling of the NE Dalradian. Journal of the Geological Society (London), 152, 383-390.

Dempster, T. J., Rogers, G., Tanner, P. W. G., Bluck, B. J., Muir, R. J., Redwood, S. D., Ireland, T. R. \& Paterson, B. A., 2002. Timing of deposition, orogenesis and glaciation within the Dalradian rocks of Scotland: Constraints from $\mathrm{U}-\mathrm{Pb}$ zircon ages. Journal of the Geological Society, 159, 83-94.

Dewey, J. F., 2005. Orogeny can be very short. Proceedings of the National Academy of Sciences of the United States of America, 102, 15286-15293.

Dewey, J. F., Dalziel, I. W., Reavy, R. J. \& Strachan, R. A., 2015. The Neoproterozoic to MidDevonian evolution of Scotland: a review and unresolved issues. Scottish Journal of Geology, 51, 5-30.

This article is protected by copyright. All rights reserved. 
Dewey, J. F. \& Shackleton, R. M., 1984. A model for the evolution of the Grampian tract in the early Caledonides and Appalachians. Nature, 312, 115-121.

Dorais, M. J. \& Spencer, C. J., 2014. Revisiting the importance of residual source material (restite) in granite petrogenesis: The Cardigan Pluton, New Hampshire. Lithos, 202-203, 237-249.

Droop, G. T. R. \& Charnley, N. R., 1985. Comparative geobarometry of pelitic hornfelses associated with the Newer Gabbros: a preliminary study. Journal of the Geological Society (London), 142, 53-62.

Droop, G. T. R. \& Harte, B., 1995. The effect of Mn on the phase relations of mediumgrade pelites: Constraints from natural assemblages on petrogenetic grid topology. Journal of Petrology, 36, 1549-1578.

Elles, G. L., 1931. Notes on the Portsoy Coastal District. Geological Magazine, 68, 24-34.

Evans, T. P., 2004. A method for calculating effective bulk composition modification due to crystal fractionation in garnet-bearing schist: Implications for isopleth thermobarometry. Journal of Metamorphic Geology, 22, 547-557.

Fettes, D. J., 1970. The structural and metamorphic state of the Dalradian rocks and their bearing on the age of emplacement of the basic sheet. Scottish Journal of Geology, 6, 108-118.

Fettes, D. J., Graham, C. M., Harte, B. \& Plant, J. A., 1986. Lineaments and basement domains: an alternative view of Dalradian evolution. Journal of the Geological Society, 143, 453-464.

Fettes, D. J., Leslie, A. G., Stephenson, D. \& Kimbell, S. F., 1991. Disruption of Dalradian stratigraphy along the Portsoy Lineament from new geological and magnetic surveys. Scottish Journal of Geology, 27, 57-73.

Goodman, S., 1991. The Pannanich Hill Complex and the origin of Crinan Subgroup migmatites in the north-eastern and central Highlands. Scottish Journal of Geology, 27, 147-156.

Goodman, S., 1994. The Portsoy-Duchray Hill Lineament: a review of the evidence. Geological Magazine, 131, 407-415.

Halliday, A. N., Graham, C. M., Aftalion, M. \& Dymoke, P., 1989. The depositional age of the Dalradian supergroup: $\mathrm{U}-\mathrm{Pb}$ and $\mathrm{Sm}-\mathrm{Nd}$ isotopic studies of the Tayvallich Volcanics, Scotland. Journal of the Geological Society (London), 146, 3-6.

Harmon, R. S., 1984. Stable isotope geochemistry of Caledonian granitoids from the British Isles and east Greenland. Physics of the earth and planetary interiors, $\mathbf{3 5}$, 105-120.

Harte, B. \& Hudson, N. F. C., 1979. Pelite facies series and the temperatures and pressures of Dalradian metamorphism in E Scotland. In: Harris, A.L., Holland, C.H., Leake, B.E. (Eds.), The Caledonides of the British Isles-Reviewed. Special Publication of the Geological Society of London, No. 8. pp. 323-337.

Holland, T. J. B. \& Powell, R., 2011. An improved and extended internally consistent thermodynamic dataset for phases of petrological interest, involving a new equation of state for solids. Journal of Metamorphic Geology, 29, 333-383.

Hudson, N. F. C., 1980. Regional metamorphism of some Dalradian pelites in the Buchan area, N.E. Scotland. Contributions to Mineralogy and Petrology, 73, 39-51.

Johnson, M., 1962. Relations of movement and metamorphism in the Dalradians of Banffshire. Transactions of the Edinburgh Geological Society, 19, 29-64.

Johnson, M. \& Stewart, F., 1960. On Dalradian structures in north-east Scotland. Transactions of the Edinburgh Geological Society, 18, 94-103.

This article is protected by copyright. All rights reserved. 
Johnson, T. E., 1999. Partial melting in Dalradian pelitic migmatites from the Fraserburgh-Inzie Head area of Buchan, northeast Scotland. Unpublished PhD Thesis, University of Derby.

Johnson, T. E., Hudson, N. F. C. \& Droop, G. T. R., 2000. Wollastonite-bearing assemblages from the Dalradian at Fraserburgh, northeast Scotland and their bearing on the emplacement of garnetiferous granitoid sheets. Mineralogical Magazine, 64, 1165-1176.

Johnson, T. E., Hudson, N. F. C. \& Droop, G. T. R., 2001a. Melt segregation structures within the inzie head gneisses of the Northeastern Dalradian. Scottish Journal of Geology, 37, 59-72.

Johnson, T. E., Hudson, N. F. C. \& Droop, G. T. R., 2001b. Partial melting in the Inzie Head gneisses: The role of water and a petrogenetic grid in KFMASH applicable to anatectic pelitic migmatites. Journal of Metamorphic Geology, 19, 99-118.

Johnson, T. E., Hudson, N. F. C. \& Droop, G. T. R., 2003. Evidence for a genetic granitemigmatite link of the Dalradian of NE Scotland. Journal of the Geological Society, 160, 447-457.

Kneller, B. C., 1987a. A geological history of north-east Scotland. In: Geology of the Aberdeen Area (eds Trewin, N. H., Kneller, B. C. \& Gillen, C.), pp. 1-50. Scottish Academic Press, Edinburgh.

Kneller, B. C., 1987b. The gneisses of Cairnbulg. In: Geology of the Aberdeen Area (eds Trewin, N. H., Kneller, B. C. \& Gillen, C.), pp. 107 \pm 111 . Scottish Academic Press, Edinburgh.Kneller, B. C. \& Aftalion, M., 1987. The isotopic and structural age of the Aberdeen granite ( Scotland). Journal of the Geological Society (London), 144, 717-721.

Kneller, B. C. \& Leslie, A. G., 1984. Amphibolite facies metamorphism in shear zones in the Buchan area of NE Scotland. Journal of Metamorphic Geology, 2, 83-94.

Konrad-Schmolke, M., Handy, M. R., Babist, J. \& O'Brien, P. J., 2005. Thermodynamic modelling of diffusion-controlled garnet growth. Contributions to Mineralogy and Petrology, 149, 181-195.

Lambert, R. S. J. \& McKerrow, W. S., 1976. The Grampian Orogeny. Scottish Journal of Geology, 12, 271-292.

Mahar, E. M., Baker, J. M., Powell, R., Holland, T. J. B. \& Howell, N., 1997. The effect of Mn on mineral stability in metapelites. Journal of Metamorphic Geology, 15, 223-238.

Marchildon, N. \& Brown, M., 2003. Spatial distribution of melt-bearing structures in anatectic rocks from Southern Brittany, France: implications for melt transfer at grain-to orogen-scale. Tectonophysics, 364, 215-235.

Munro, M. \& Gallagher, J., 1984. Disruption of the 'Younger Basic'masses in the HuntlyPortsoy area, Grampian Region. Scottish Journal of Geology, 20, 361-382.

Oliver, G. J. H., 2001. Reconstruction of the grampian episode in Scotland: Its place in the Caledonian orogeny. Tectonophysics, 332, 23-49.

Oliver, G. J. H., Chen, F., Buchwaldt, R. \& Hegner, E., 2000. Fast tectonometamosphism and exhumation in the type area of the Barrovian and Buchan zones. Geology, 28, 459-462.

Oliver, G. J. H., Martin, M. W. \& Banks, G. 2002. Origin of the tectonised 470 Ma 'Older Basic' Complex, NE Scotland. In: Tectonic Studies Group Annual Meeting Abstracts. University of Leicester, Leicester, 55.

Oliver, G. J. H., Wilde, S. A. \& Wan, Y., 2008. Geochronology and geodynamics of Scottish granitoids from the late neoproterozoic break-up of Rodinia to Palaeozoic collision. Journal of the Geological Society, 165, 661-674.

This article is protected by copyright. All rights reserved. 
Pattison, D. R. \& Tracy, R. J., 1991. Phase equilibria and thermobarometry of metapelites. Reviews in Mineralogy and Geochemistry, 26, 105-206.

Pearce, M., White, A. \& Gazley, M., 2015. TCInvestigator: automated calculation of mineral mode and composition contours for thermocalc pseudosections. Journal of Metamorphic Geology, 33, 413-425.

Pidgeon, R. \& Aftalion, M., 1978. Cogenetic and inherited zircon U-Pb systems in granites: Palaeozoic granites of Scotland and England. In: Crustal evolution in northwestern Britain and adjacent regions, pp. 183-220, Scottish Academic Press Glasgow.

Powell, R. \& Holland, T. J. B., 1988. An internally consistent dataset with uncertainties and correlations: 3. Applications to geobarometry, worked examples and a computer program. Journal of Metamorphic Geology, 6, 173-204.

Ramsay, D. M. \& Sturt, B. A., 1979. The status of the Banff nappe. In: Harris, A.L., Holland, C.H., Leake, B.E. (eds), The Caledonides of the British Isles-Reviewed. Special Publication of the Geological Society of London, No. 8. pp. 145-151.

Read, H., 1919. IV.-The Two Magmas of Strathbogie and Lower Banffshire. Geological Magazine (Decade VI), 6, 364-371.

Read, H. H., 1923. The Geology of the Country Round Banff, Huntly and Turriff (lower Banffshire and North-west Aberdeenshire). HM Stationery Office.

Read, H.H., 1952. Metamorphism and migmatisation in the Ythan Valley, Aberdeenshire. Transactions of the Edinburgh Geological Society, 15, 265-279.

Read, H., 1955. The Banff Nappe: an interpretation of the structure of the Dalradian rocks of north-east Scotland. Proceedings of the Geologists' Association, 66, 1-29.

Read, H. H. \& Farquhar, O. C., 1956. The Buchan anticline of the Banff Nappe of Dalradian rocks in North-East Scotland. Quarterly Journal of the Geological Society of London, 112, 131-156.

Rosenberg, C. L. \& Handy, M. R., 2005. Experimental deformation of partially melted granite revisited: implications for the continental crust. Journal of Metamorphic Geology, 23, 19-28.

Spear, F. S., 1988. Metamorphic fractional crystallization and internal metasomatism by diffusional homogenization of zoned garnets. Contributions to Mineralogy and Petrology, 99, 507-517.

Stephenson, D. \& Gould, D. E., 1995. British Regional Geology - The Grampian Highlands. HMSO for the British Geological Survey, London.

Stephenson, D., Mendum, J. R., Fettes, D. J. \& Leslie, A. G., 2013a. The Dalradian rocks of Scotland: An introduction. Proceedings of the Geologists' Association, 124, 3-82.

Stephenson, D., Mendum, J. R., Fettes, D. J., Smith, C. G., Gould, D., Tanner, P. W. G. \& Smith, R. A., 2013b. The Dalradian rocks of the north-east Grampian Highlands of Scotland. Proceedings of the Geologists' Association, 124, 318-392.

Stevens, G., Villaros, A. \& Moyen, J.-F., 2007. Selective peritectic garnet entrainment as the origin of geochemical diversity in S-type granites. Geology, 35, 9-12.

Sturt, B. A., Ramsay, D. M., Pringle, I. R. \& Teggin, D. E., 1977. Precambrian gneisses in the Dalradian sequence of northeast Scotland. Journal of the Geological Society, 134, 41-44.

Sutton, J. \& Watson, J., 1956. The Boyndie syncline of the Dalradian of the Banffshire Coast. Quarterly Journal of the Geological Society of London, 112, 103-130.

Symmes, G. H. \& Ferry, J. M., 1992. The effect of whole-rock MnO content on the stability of garnet in pelitic schists during metamorphism. Journal of Metamorphic Geology, 10, 221-237.

This article is protected by copyright. All rights reserved. 
Tanner, P. W. G., 1996. Significance of the early fabric in the contact metamorphic aureole of the 590 Ma Ben Vuirich Granite, Perthshire, Scotland. Geological Magazine, 133, 683-695.

Tanner, P. W. G., 2014. A kinematic model for the Grampian Orogeny, Scotland. In: Geological Society Special Publication, pp. 467-511.

Tanner, P. W. G., Leslie, A. G. \& Gillespie, M. R., 2006. Structural setting and petrogenesis of the Ben Vuirich granite Pluton of the Grampian Highlands: A pre-orogenic, riftrelated intrusion. Scottish Journal of Geology, 42, 113-136.

Tilley, C. E., 1925. A preliminary survey of metamorphic zones in the Southern Highlands of Scotland. Quarterly Journal of the Geological Society of London, 81, $100-112$.

Treagus, J. E. \& Roberts, J. L., 1981. The Boyndie syncline, a D1 structure in the Dalradian of Scotland. Geological Journal, 16, 125-135.

Trewin, N. H. \& Rollin, K. E., 2002. Geological history and structure of Scotland. In: Trewin, N. H. (ed.) The Geology of Scotland. Geological Society, London, 1-26.

Viete, D. R., Oliver, G. J., Fraser, G. L., Forster, M. A. \& Lister, G. S., 2013. Timing and heat sources for the Barrovian metamorphism, Scotland. Lithos, 177, 148-163.

Viete, D., Oliver, G. \& Wilde, S., 2014. Discussion of 'Metamorphic P-T and retrograde path of high-pressure Barrovian metamorphic zones near Cairn Leuchan, Caledonian orogen, Scotland'. Geological Magazine, 151, 755-758.

Viete, D. R., Richards, S. W., Lister, G. S., Oliver, G. J. H. \& Banks, G. J., 2010. Lithosphericscale extension during Grampian orogenesis in Scotland. In: Geological Society Special Publication, pp. 121-160.

White, R. W., Powell, R., Holland, T. J. B., Johnson, T. E. \& Green, E. C. R., 2014a. New mineral activity-composition relations for thermodynamic calculations in metapelitic systems. Journal of Metamorphic Geology, 32, 261-286.

White, R. W., Powell, R. \& Johnson, T. E., 2014b. The effect of Mn on mineral stability in metapelites revisited: New a-x relations for manganese-bearing minerals. Journal of Metamorphic Geology, 32, 809-828.

\section{SUPPORTING INFORMATION}

Additional Supporting Information may be found in the online version of this article at the publisher's website:

Figure S1. Contour maps showing the abundance of phases (mol.\%) for the average Argyll Group metapelite composition of Atherton \& Brotherton (1982).

Figure S2. Contour maps showing the abundance of phases (mol.\%) for the average Argyll Group metapelite composition with 0.5 mol.\% spessartine-rich garnet removed.

Figure S3. (a) $T-X\left(\mathrm{H}_{2} \mathrm{O}\right)$ and (b) $P-X$ (melt loss) pseudosections showing the effect of variable $\mathrm{H}_{2} \mathrm{O}$ contents and melt loss, respectively, on phase relations for the garnet-depleted composition.

Table S1. Bulk compositions used in the construction of Fig. S3.

Received 19 May 2015; revision accepted 19 June 2015.

This article is protected by copyright. All rights reserved. 


\section{FIGURE CAPTIONS}

Fig. 1. (a) Simplified geological map of the northeast Grampian Highlands (modified after Viete et al., 2010; fig. 3 with additional data from Read, 1952). (b) Coastal section between Fraserburgh and St Combs showing the location of the detailed maps shown in c and d. Inset shows the location of the study area within Scotland. (c) Geological map of uppermost Argyll Group (locally Strichen Formation) middle Dalradian rocks around Fraserburgh. The boundary with Southern Highland Group rocks (upper Dalradian) is around $500 \mathrm{~m}$ further to the west. The first clear evidence for partial melting (the 'melt'-in isograd) lies between Broadsea Shore and Kinnaird Head. Garnet-bearing aplites are abundant between Kinnaird Head and the harbour. (d) Geological map of the Inzie Head Gneiss Formation (probably Crinan Subgroup). Sheets of diorite and granite are abundant (although the position of these is not extrapolated inland due to lack of exposure). Isograds within the Inzie Head Gneiss Formation record the first prograde appearance of garnet and, at high grades, orthopyroxene. Garnet disappears 50-100 m southeast of the orthopyroxene isograd. Contains Ordnance Survey data (C) Crown Copyright (and database right) 2013.

Fig. 2. Field photos. (a) Composite aplite-pegmatite sheet within dark, biotite-rich metapelitic rocks at Kinnaird Head (Fig. 1). (b) Close up of contact between aplite and metapelite. The aplite contains abundant small $(0.5 \mathrm{~mm})$ grains of euhedral garnet; the metapelite contains small porphyroblasts of cordierite and (metastable) andalusite and contains abundant fibrolite. Thin irregular veins of granite (leucosome) derived from in situ melting of the metapelite interconnect with, and feed into, the garnetiferous aplite. (c) Typical diatexite around West Haven on the east side of Fraserburgh Bay (Fig. 1). Schollen of residual metapelite, semipelite and calcareous psammite are abundant, along with biotiterich schieren. Irregular leucosome veins containing retrogressed cordierite interconnect with larger granite sheets (left). (d) Typical garnet-bearing diatexite at Point of Whitelinks (Fig. 1). 'Flame'-like leucosome containing large porphyroblasts of partially retrogressed garnet (see inset) mingles with grey leucosome containing abundant cordierite but no garnet. These diatexites contain small rounded schollen of cordierite-spotted metapelite (bottom) and larger fragments of pale calcareous psammite (top). (e) Typical coarse-grained granofelsic diatexite close to St Combs. Stubby dark-green prismatic pseudomorphs are interpreted to replace orthopyroxene. Garnet occurs with orthopyroxene pseudomorphs a short distance to the northwest (at lower grades) but not in these rocks or those at higher grades around Inzie Head. (f) Magma mingling between the large diorite sheet near St Combs and a porphyritic granite that represents segregated leucosome derived from the diatexites.

Fig. 3. Phase equilibria modelling using the average composition of Argyll Group (middle Dalradian) metapelites of Atherton \& Brotherton (1982; table 5) with a reduced $\mathrm{H}_{2} \mathrm{O}$ content (3 mol.\%). (a) $P-T$ pseudosection from $1.0-5.5 \mathrm{kbar}$ and $660-820{ }^{\circ} \mathrm{C}$ spanning high- $T$ subsolidus to suprasolidus conditions. Although this diagram reproduces well near solidus phase relations (see b), at higher temperature garnet coexists with orthopyroxene at all but the lowest pressures $(<1.5 \mathrm{kbar}$ ). The prograde growth of orthopyroxene at high- $T$ requires pressures of 3 kbar or less. (b) Expanded region of (a) showing near solidus phase relations. An isobaric (2.75 kbar) metamorphic field gradient (grey arrow) is shown that is consistent with observations. Along the preferred field gradient the subsolidus evolution (for which the $\mathrm{H}_{2} \mathrm{O}$ content is artificially low) predicts assemblages containing cordierite, biotite and andalusite cross the andalusite to sillimanite transition before crossing the $\mathrm{H}_{2} \mathrm{O}$-saturated

This article is protected by copyright. All rights reserved. 
solidus at $680-685{ }^{\circ} \mathrm{C}$, which coincides with the prograde formation of garnet, consistent with the production of the garnet-bearing aplites.

Fig. 4. Calculated abundance of (a) melt and (b) garnet for the $P-T$ pseudosection for the average Argyll Group metapelite (Fig. 3a) as mol.\% normalised to one oxide to approximate volume percent. (c) Calculated composition of garnet in terms of the mole fraction of the spessartine component, $X($ spss $),=\mathrm{Mn} /(\mathrm{Mn}+\mathrm{Fe}+\mathrm{Mg}+\mathrm{Ca})$.

Fig. 5. $T-X(\mathrm{MnO})$ pseudosection at 2.75 kbar varying from the average Argyll Group metapelite $(\mathrm{MnO}=0.09 \mathrm{~mol} \% ; X=0)$ to a composition with $0.6 \mathrm{~mol} \%$ spessartine-rich garnet removed ( $X=1$ with $0.005 \mathrm{~mol} \% \mathrm{MnO}$ ). The composition of the garnet is that measured (by EPMA) from the core of a grain within an aplite sheet on Kinnaird Head. The only significant effect is the stability of garnet that, at temperatures below the prograde appearance of orthopyroxene, increases to significantly higher temperature with decreasing $\mathrm{MnO}$ content. The grey arrows show isobaric metamorphic field gradients consistent with field observations. The subsolidus evolution is reproduced by the average composition with $0.09 \mathrm{~mol} . \% \mathrm{MnO}(X=0)$. The suprasolidus evolution requires a significant reduction in $\mathrm{MnO}$, for example $X=0.8$, which corresponds to removal of around $0.5 \mathrm{~mol} \%$ spessartinerich garnet. For the suprasolidus prograde evolution of this composition, the appearance of garnet (i.e. the garnet in isograd) is predicted at around $760{ }^{\circ} \mathrm{C}$, the prograde appearance of orthopyroxene is predicted at around $785^{\circ} \mathrm{C}$ and the prograde consumption of garnet is predicted at around $790-800{ }^{\circ} \mathrm{C}$.

Fig. 6. $P-T$ pseudosection from $1.0-5.5 \mathrm{kbar}$ and $660-820{ }^{\circ} \mathrm{C}$ for the average Argyll Group metapelite with 0.5 mol.\% spessartine-rich garnet removed ( $X=0.8$ in Fig. 5). The grey arrow shows an isobaric metamorphic field gradient that is consistent with field observations.

Fig. 7. Calculated abundance of (a) melt and (b) garnet for the garnet- (and MnO-) depleted composition modelled in Fig. 6 as mol.\% normalised to one oxide to approximate volume percent. (c) Calculated composition of garnet in terms of the mole fraction of the spessartine component, $X($ spss $),=$ molar $\mathrm{Mn} /(\mathrm{Mn}+\mathrm{Fe}+\mathrm{Mg}+\mathrm{Ca})$.

Table 1. Normalised bulk compositions used in the calculation of phase diagrams in mol.\%.

\begin{tabular}{|c|c|c|c|c|c|c|c|c|c|c|c|c|}
\hline & $\mathrm{H}_{2} \mathrm{O}$ & $\mathrm{SiO}_{2}$ & $\mathbf{A l}_{2} \mathbf{O}_{3}$ & $\mathrm{CaO}$ & MgO & $\mathrm{FeO}$ & $\mathrm{K}_{2} \mathrm{O}$ & $\mathrm{Na}_{2} \mathrm{O}$ & $\mathrm{TiO}_{2}$ & MnO & O & TOTAL \\
\hline Fig. 3 & 3.108 & \#\#\#\#\# & \#\#\#\# & 1.373 & 4.693 & 7.200 & 2.424 & 2.020 & 0.777 & 0.093 & 0.787 & 100 \\
\hline Fig. 5 (1 & 3.108 & \#\#\#\# & \#\#\#\# & 73 & 4.6 & 7.200 & 2.424 & 2.020 & 0.777 & 0.093 & 0.787 & 100 \\
\hline Fig. 5 ( & 3.110 & \#\#\#\#\# & \#\#\#\# & 1.379 & 4.717 & 7.049 & 2.436 & 2.042 & 0.777 & 0.005 & 0.788 & 100 \\
\hline Fig. 6; Fig. 7 & 3.110 & \#\#\#\# & \#\#\#\# & 1.378 & 4.712 & 7.079 & 2.434 & 2.038 & 0.777 & 0.023 & 0.788 & 100 \\
\hline
\end{tabular}

This article is protected by copyright. All rights reserved. 

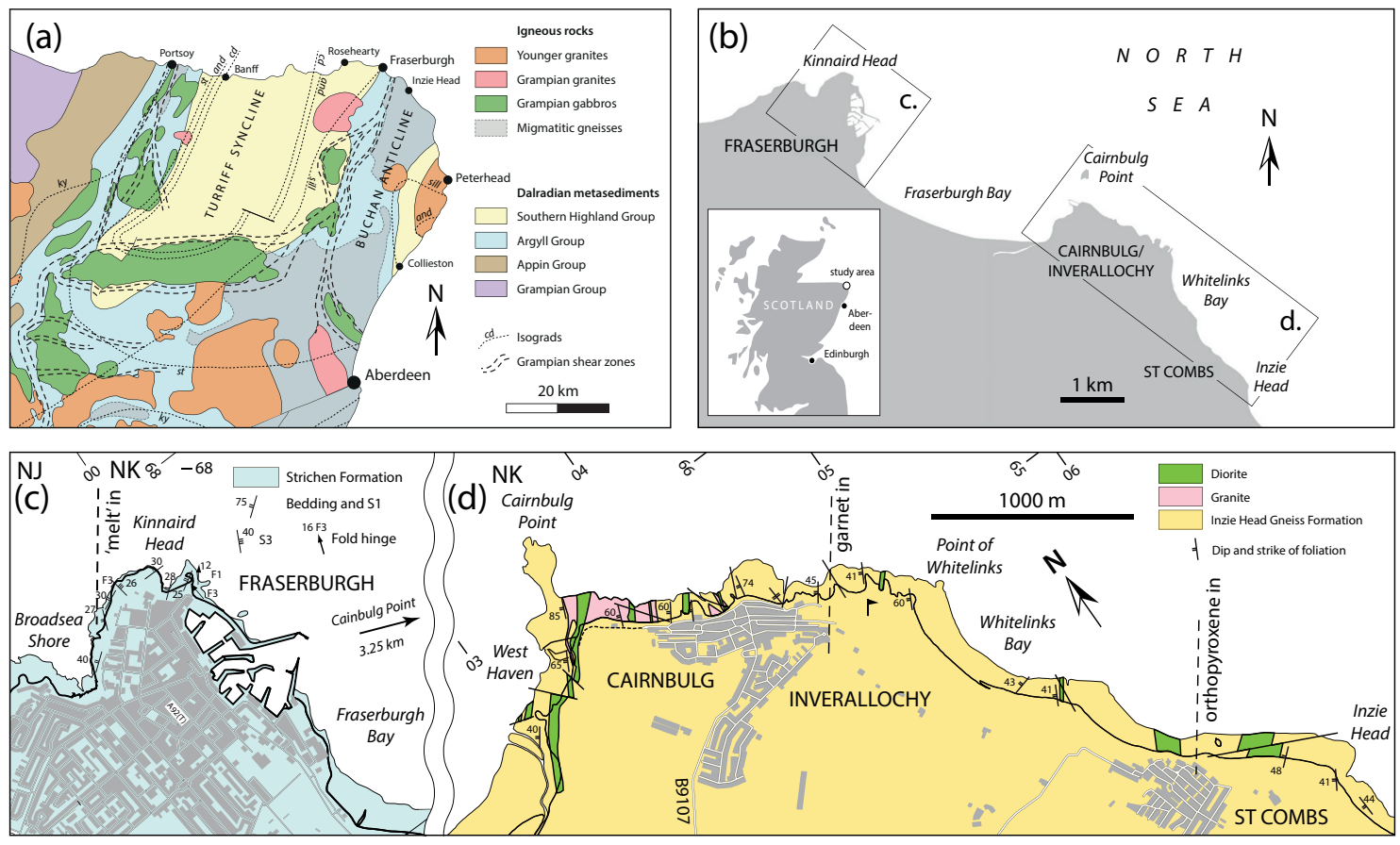

Figure 1

This article is protected by copyright. All rights reserved. 

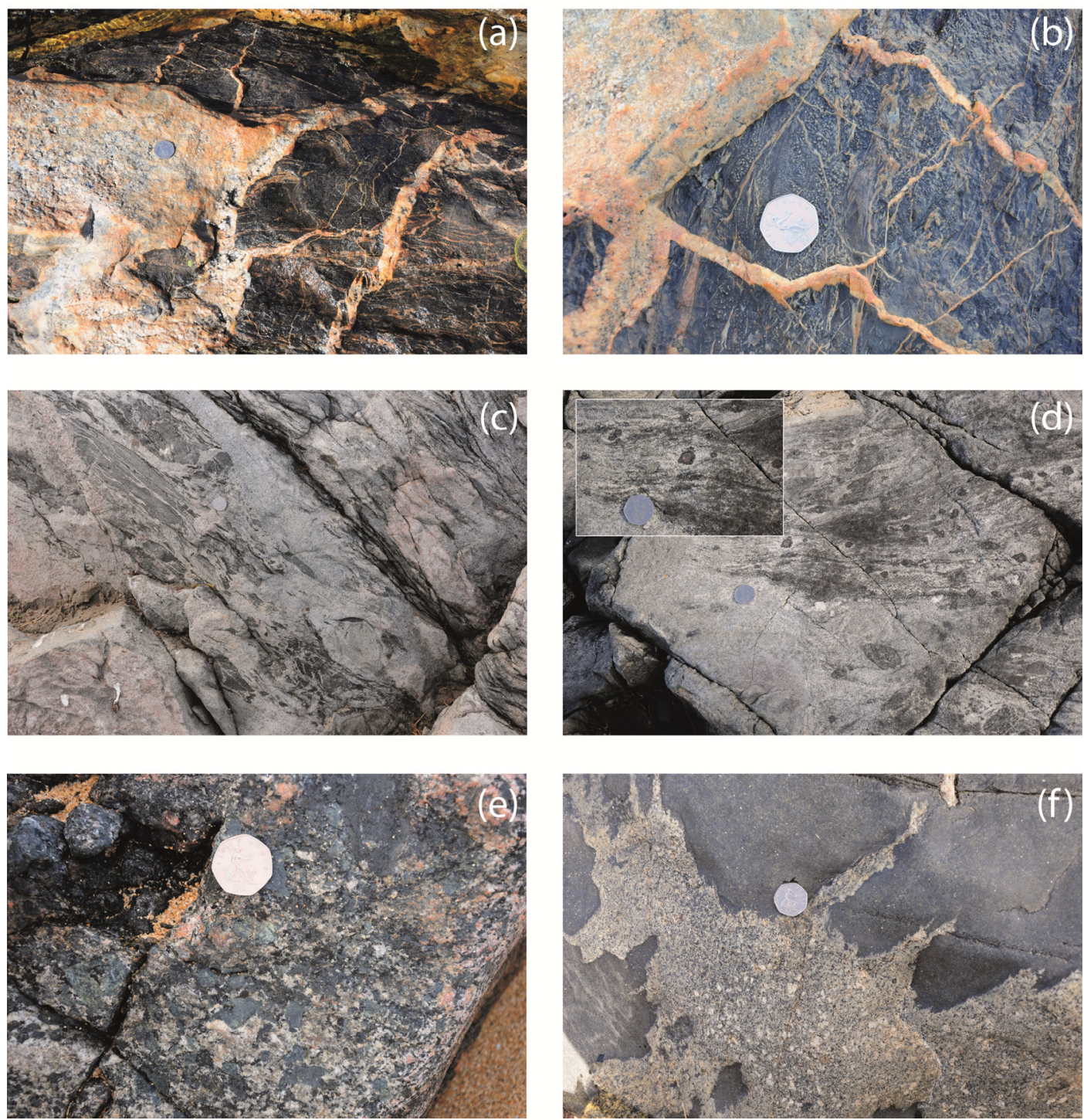

Figure 2

This article is protected by copyright. All rights reserved. 


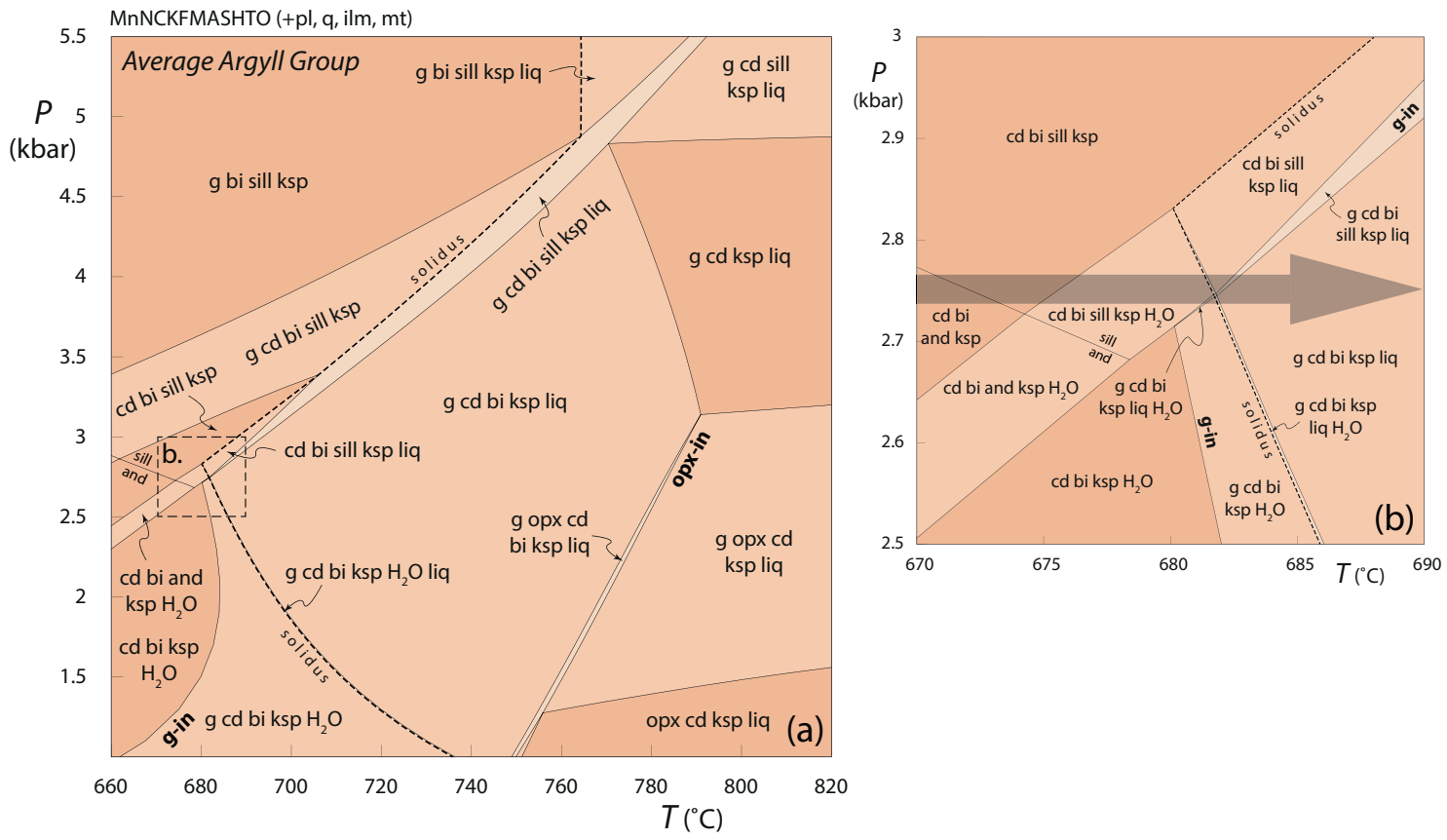

This article is protected by copyright. All rights reserved. 

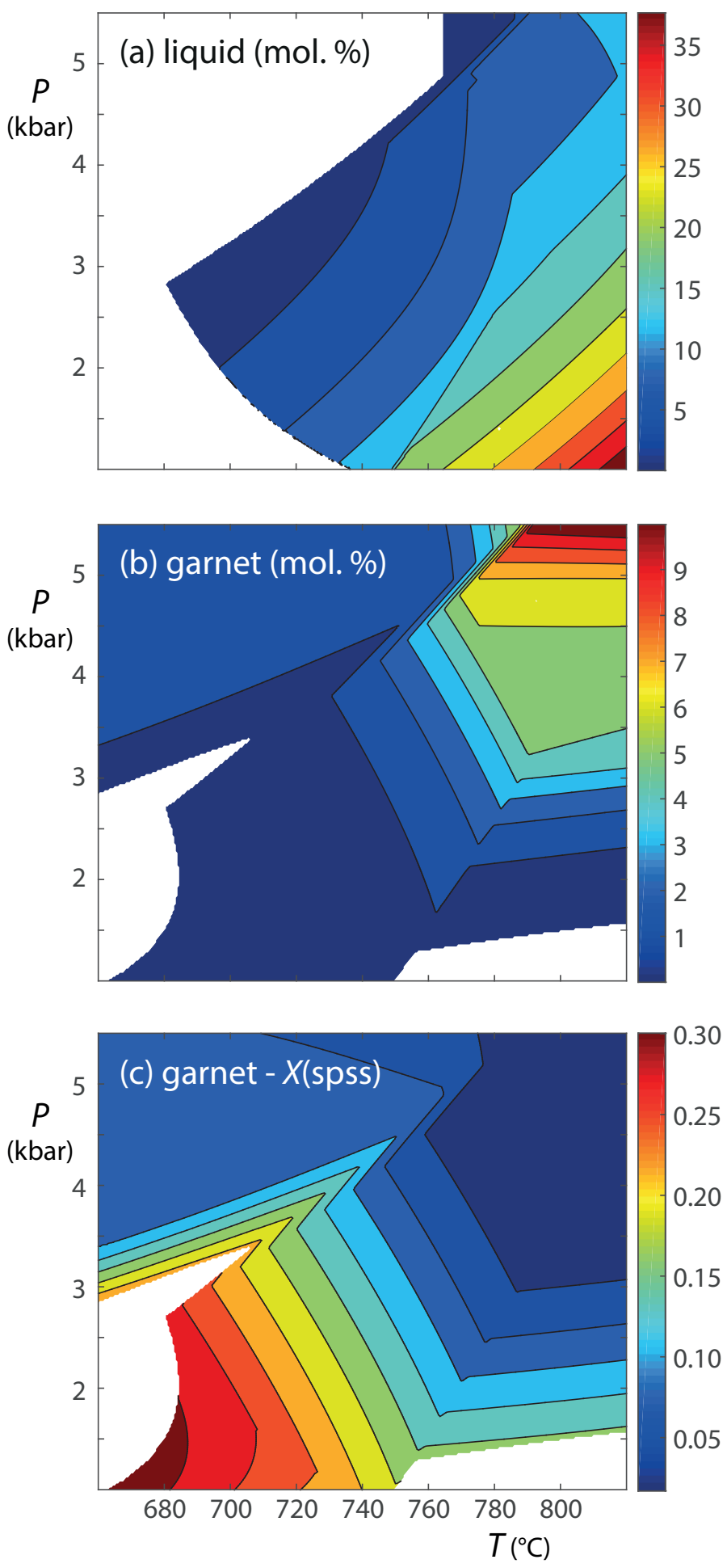

Figure 4 


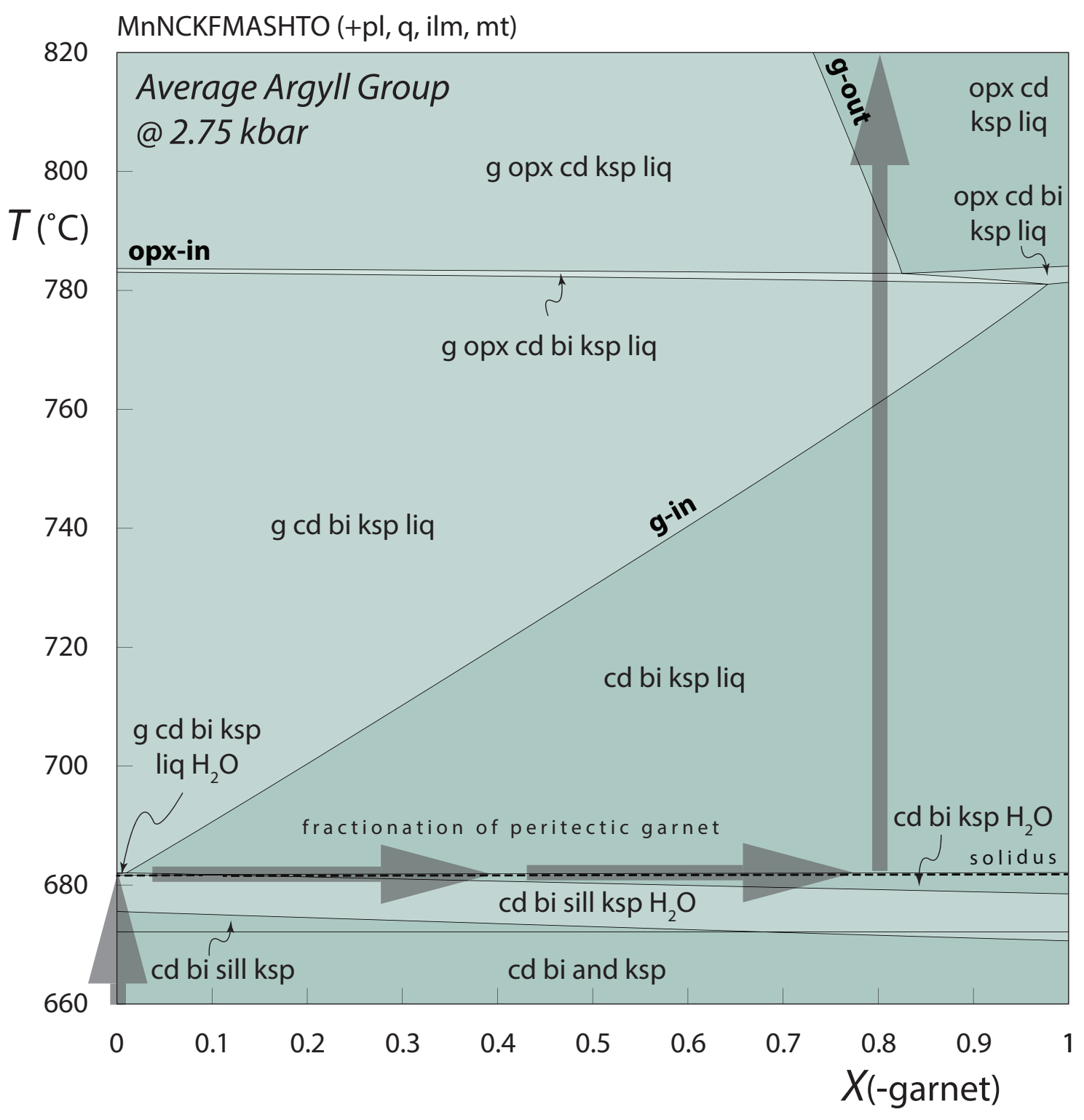

Figure 5

This article is protected by copyright. All rights reserved. 


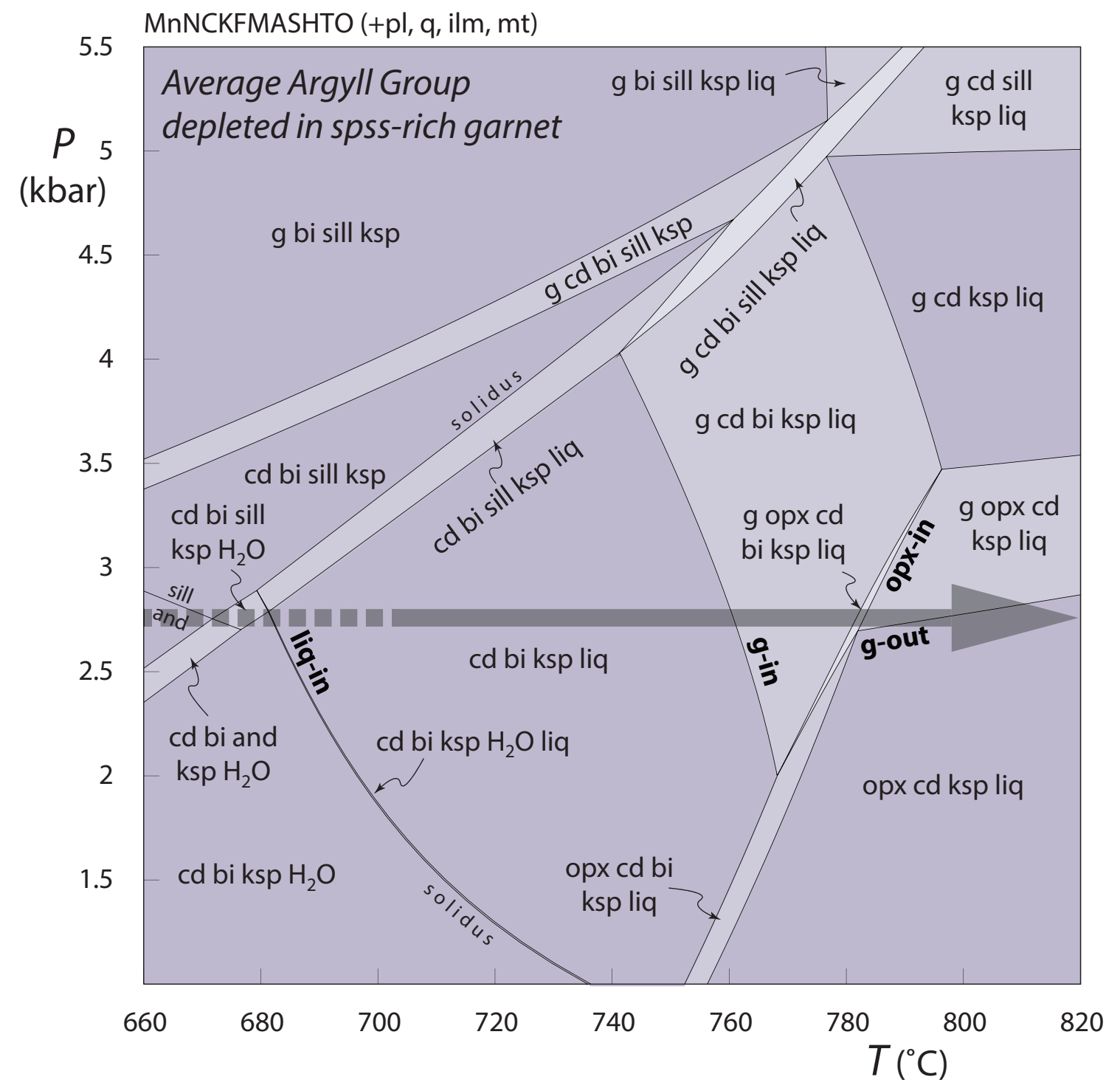

Figure 6

This article is protected by copyright. All rights reserved. 

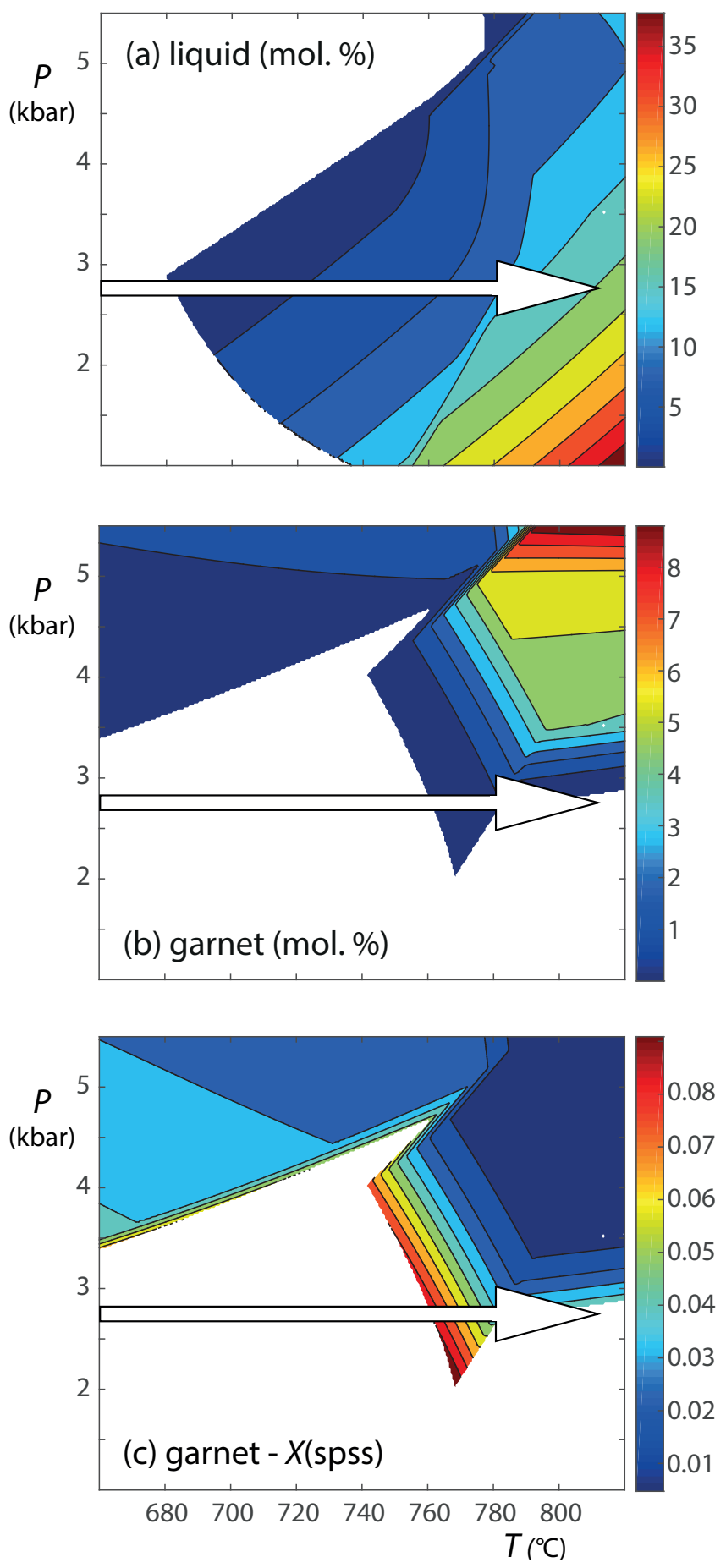

Figure 7

This article is protected by copyright. All rights reserved. 